\title{
A social work study on the effect of different factors on leadership style: A case study of educational system
}

\author{
Hajar Jannesari $^{a^{*}}$, Mahdi Khorvash ${ }^{\mathrm{b}}$ and Mohammad Reza Iravanic
}

\begin{abstract}
${ }^{a}$ MS Student, Counseling Department, Islamic Azad University of Khomeinishahr, Khomeinishahr Branch, Daneshjou Blvd, Iran
${ }^{b}$ Counseling Department, Islamic Azad University of Khomeinishahr, Khomeinishahr Branch, Daneshjou Blvd, Iran

${ }^{c}$ Assistant Professor, Department of Social Work, Islamic Azad University Khomeinishahr Branch, Daneshjou Blvd, Iran

C H R O N I C L E

Article history:

Received October 14, 2012

Received in revised format

26 December 2012

Accepted 10 January 2013

Available online

January 122013

Keywords:

Leadership style

Educational system

Transformational leadership

Transactional leadership

\section{A B S T R A C T}

Leadership style plays an important role on job satisfaction in educational systems. In this paper, we present a study among 180 school principals in city of Khomeinishahr, located in province of Esfahan, Iran. The study selects a sample of 123 principals and examines ten hypotheses including the effects of personality trait neuroticism, extroversion, resilience, participative, conscientiousness on job satisfaction. The study also investigates the impacts of transformational leadership style, transactional leadership style and Laissez - fair leadership style on job satisfaction. Finally, the study considers the relationship between personality trait neuroticism and transformational leadership style as well as personality trait extraversion and transformational leadership style. The study uses Pearson correlation test and verify that nine out of ten hypotheses have been confirmed and the relationship between Laissez - fair leadership style and job satisfaction is not confirmed.
\end{abstract}

(c) 2013 Growing Science Ltd. All rights reserved.

\section{Introduction}

Leadership style plays an important role on job satisfaction in educational systems and a good principal could lead students to reach better results. There are literally different studies associated with leadership style and job satisfaction. Minoretti et al. (2006) investigated whether high levels of neuroticism and low self-esteem were markers for vulnerability to depression. They used a multivariate regression analysis and reported that neuroticism was a statistically significant, independent predictor of QTc duration in their test. Takano et al. (2007) investigated the relationship between neuroticism personality trait and serotonin transporter binding and concluded that Serotonin transporter binding in the thalamus might be a marker of vulnerability to depression. Turiano et al. (2013) investigated big 5 personality traits and interleukin-6 by looking into some evidence for "healthy Neuroticism” in a US population sample.

*Corresponding author. Tel: + 989131704487

E-mail addresses: hajar.jannesari@iaukhsh.ac.ir. (H. Jannesari) 
Max Chochinov et al. (2006) studied personality, neuroticism, and coping towards the end of life. Lin and Worthley (2012) investigated servicescape moderation on personality traits, emotions, satisfaction, and behaviors. They extended the previous servicescape literature and investigated servicescapes as a moderating variable on a comprehensive model of individual personality traits, emotions, satisfaction, and approach-avoidance behaviors. Di Fabio and Busoni (2007) studied fluid intelligence, personality traits and scholastic success in an empirical investigation in a sample of Italian high school students.

In this paper, we present a study among 180 school principals in city of Khomeinishahr, located in province of Esfahan, Iran. The organization of this paper first presents details of the proposed study in section 2 while section 3 studis th rsults of our survey and finally concluding remarks are given in the last to summarizes the contribution of the paper.

\section{The proposed study}

In this paper, we present a study among 180 school principals in city of Khomeinishahr, located in province of Esfahan, Iran. The study selects a sample of 123 principals and examines ten hypotheses as follows,

1. The first five hypotheses consider the relationship between five personality traits and job satisfaction as follows,

$$
\begin{aligned}
& \left\{\begin{array}{r}
H_{0} \text { : There are no relationship between personality trait neuroticism, extroversion, } \\
\text { resilience, participative, conscientiousness and job satisfaction. }
\end{array}\right. \\
& H_{1} \text { : There are some relationship between personality trait neuroticism, extroversion, } \\
& \text { resilience, participative, conscientiousness and job satisfaction. }
\end{aligned}
$$

Three other hypotheses of this study consider the relationship between transactional, transformational leadership styles and job satisfaction. The ninth hypothesis studies the relationship between personality trait neuroticism and transformational leadership style. Finally, The last hypothesis studies the relationship between personality trait extraversion and transformational leadership style.

\footnotetext{
$\left\{H_{0}\right.$ : There is no relationship between personality trait extraversion and transformational leadership style.

$H_{1}$ : There is a relationship between personality trait extraversion and transformational leadership style.
}

To test the above ten hypotheses, we use Pearson correlation test. The population of our survey consists of 180 principles who were working in different levels of elementary, guided and high school. Therefore, we have,

$$
n=\frac{N \times z_{\alpha / 2}^{2} \times p \times q}{\varepsilon^{2} \times(N-1)+z_{\alpha / 2}^{2} \times p \times q},
$$

where $N$ is the population size, $p=1-q$ represents the yes/no categories, $z_{\alpha / 2}$ is CDF of normal distribution and finally $\varepsilon$ is the error term. Since we have $p=0.5, z_{\alpha / 2}=1.96$ and $N=180$, the number of sample size is calculated as $n=123$. A questionnaire consists of 60 questions for five groups of hypotheses have been designed and Cronbach alpha (Cronbach, 1951) has been calculated for different hypotheses, which were all well above the mimimum level of 0.70 . In our servey, there were 48 men, 60 women. In our survey, 28 people were less than 28 years of age, 47 people were between 35 and 45 years of age and 34 people were older than 45 years. In terms of educational background, 17 people only finished high school, 24 principles finshed a 2-year college, 49 people hold bachelour degree and 18 principles had master degree. 


\section{The results}

\subsection{The first hypothesis: Personality trait neuroticism and job satisfaction}

The first hypothesis of this survey is associated with the relationship between personality trait neuroticism and job satisfaction. Table 1 shows details of our findings,

\section{Table 1}

The results of Pearson correlation test between personality trait neuroticism and job satisfaction

\begin{tabular}{lllcl}
\hline Resource & Freq. & $\mathrm{r}$ & Effective coefficient & P-value \\
\hline Personality trait neuroticism and job satisfaction & 112 & 0.49 & 0.24 & 0.001 \\
\hline
\end{tabular}

As we can observe from the results of Table 1, the null hypothesis is rejected when the level of significance is one percent and we can conclude that managers with no personality trait neuroticism have more job satisfaction.

\subsection{The second hypothesis: Personality trait of extroversion and job satisfaction}

The second hypothesis of this survey studies the relationship between personality trait of extroversion and job satisfaction and Table 2 summarizes our findings,

Table 2

The results of Pearson correlation test between personality trait extroversion and job satisfaction

\begin{tabular}{llccc}
\hline Resource & Freq. & $\mathrm{r}$ & Effective coefficient & P-value \\
\hline Personality trait extroversion and job satisfaction & 112 & 0.47 & 0.22 & 0.001 \\
\hline
\end{tabular}

It is obvious from the results of Table 2, the null hypothesis can be rejected when the level of significance is one percent and we can conclude that managers with personality trait extroversion are more satisfied from their jobs.

\subsection{The third hypothesis: Personality trait resilience and job satisfaction}

The third hypothesis of this survey is associated with the relationship between personality trait resilience and job satisfaction. Table 3 presents the results,

\section{Table 3}

The results of Pearson correlation test between personality trait resilience and job satisfaction

\begin{tabular}{llccc}
\hline Resource & Freq. & $\mathrm{r}$ & Effective coefficient & P-value \\
\hline Personality trait resilience and job satisfaction & 112 & 0.61 & 0.37 & 0.001 \\
\hline
\end{tabular}

The results of Table 3 explicitly show that the null hypothesis can be rejected when the level of significance is one percent and we can conclude that managers with this kind of personality are more satisfied from their jobs.

\subsection{The fourth hypothesis: Personality trait participative and job satisfaction}

The fourth hypothesis of this survey is associated with the relationship between personality trait participative and job satisfaction. Table 4 describes the results,

\section{Table 4}

The results of Pearson correlation test between personality trait participative and job satisfaction

\begin{tabular}{llccc}
\hline Resource & Freq. & r & Effective coefficient & P-value \\
\hline Personality trait participative and job satisfaction & 112 & 0.54 & 0.29 & 0.001 \\
\hline
\end{tabular}


The results of Table 4 explicitly show that the null hypothesis can be rejected when the level of significance is one percent and we can conclude that managers with this type of personality are more satisfied from their jobs.

\subsection{The fifth hypothesis: Personality trait conscientiousness and job satisfaction}

The fifth hypothesis of this survey investigates the relationship between personality trait conscientiousness and job satisfaction. Table 5 describes the results,

\section{Table 5}

The results of Pearson correlation test between personality trait conscientiousness and job satisfaction

\begin{tabular}{lllllllll}
\hline Resource & & & & Freq. & r & Effective coefficient & P-value \\
\hline $\begin{array}{l}\text { Personality } \\
\text { satisfaction }\end{array}$ & trait & conscientiousness & and & job & 112 & 0.56 & 0.31 & 0.001 \\
\hline
\end{tabular}

The results of Table 5 clearly indicate that the null hypothesis is rejected when the level of significance is one percent and we can conclude that conscientiousness managers are more satisfied from their jobs.

3.6. The sixth hypothesis: Transformational leadership style and job satisfaction

The sixth hypothesis of this survey investigates the relationship between transformational leadership style and job satisfaction and the results are presented in Table 6.

\section{Table 6}

The results of Pearson correlation test between transformational leadership style and job satisfaction

\begin{tabular}{llllllccl}
\hline Resource & & & & & Freq. & $\mathrm{r}$ & Effective coefficient & P-value \\
\hline $\begin{array}{l}\text { Transformational } \\
\text { satisfaction }\end{array}$ & leadership & style & and & job & 112 & 0.86 & 0.73 & 0.001 \\
\hline
\end{tabular}

The results of Table 6 clearly indicate that the null hypothesis is rejected when the level of significance is one percent, there is positive and strong relationship between these two components, and we can conclude that managers with more sense of transformational leadership are more satisfied from their jobs.

\subsection{The seventh hypothesis: Transactional leadership style and job satisfaction}

The seventh hypothesis of this survey investigates the relationship between transactional leadership style and job satisfaction and the results are presented in Table 7.

\section{Table 7}

The results of Pearson correlation test between transactional leadership style and job satisfaction

\begin{tabular}{lllcl}
\hline Resource & Freq. & $\mathrm{r}$ & Effective coefficient & P-value \\
\hline Transactional leadership style and job satisfaction & 112 & 0.876 & 0.76 & 0.001 \\
\hline
\end{tabular}

The results of Table 7 clearly indicate that the null hypothesis is rejected when the level of significance is one percent, there is positive and strong relationship between these two components, and we can conclude that managers with more sense of transactional leadership are more satisfied from their jobs.

\subsection{The eighth hypothesis: Laissez - fair leadership style and job satisfaction}

The eighth hypothesis of this survey investigates the relationship between Laissez-fair leadership style and job satisfaction and the results are presented in Table 8. 
Table 8

The results of Pearson correlation test between Laissez-fair leadership style and job satisfaction

\begin{tabular}{llccc}
\hline Resource & Freq. & $\mathrm{r}$ & Effective coefficient & P-value \\
\hline Laissez-fair leadership style and job satisfaction & 112 & -0.08 & 0.006 & 0.42
\end{tabular}

The results of Table 8 do not provide any evidence to reject null hypothesis when the level of significance is either five or ten percent. In other word, there is no meaningful relationship between these two components.

\subsection{The ninth hypothesis: Personality trait neuroticism and transformational leadership style}

The ninth hypothesis of this survey investigates the relationship between personality trait neuroticism and transformational leadership style and the results are demonstrated in Table 9.

\section{Table 9}

The results of Pearson correlation test between personality trait neuroticism and transformational leadership style

\begin{tabular}{llccc}
\hline Resource & Freq. & r & Effective coefficient & P-value \\
\hline $\begin{array}{l}\text { Personality trait neuroticism and transformational } \\
\text { leadership style }\end{array}$ & 112 & 0.86 & 0.73 & 0.001 \\
\hline
\end{tabular}

The results of Table 9 show that the null hypothesis is rejected when the level of significance is one percent, there is positive and strong relationship between these two components. In other words, when there is no personality trait neuroticism, managers may switch to transformational leadership style.

\subsection{The tenth hypothesis: Personality trait extraversion and transformational leadership style}

The last hypothesis of this survey investigates the relationship between personality trait extraversion and transformational leadership style and the results are demonstrated in Table 10.

\section{Table 10}

The results of Pearson correlation test between personality trait extraversion and transformational leadership style

\begin{tabular}{llccc}
\hline Resource & Freq. & r & Effective coefficient & P-value \\
\hline $\begin{array}{l}\text { Personality trait extraversion and transformational } \\
\text { leadership style }\end{array}$ & 112 & 0.21 & 0.04 & 0.03 \\
\hline
\end{tabular}

The results of Table 10 show that the null hypothesis is rejected when the level of significance is onlu five percent and the null hypothesis cannot be rejected when the level of significance is one percent. Therefore, we can conclude that there is some weak and positive relationship between these two components.

\section{Conclusion}

In this paper, we present a study among 180 school principals in city of Khomeinishahr, located in province of Esfahan, Iran. The study examined ten hypotheses including the effects of personality trait neuroticism, extroversion, resilience, participative, conscientiousness on job satisfaction. The study also investigates the impacts of transformational leadership style, transactional leadership style and Laissez - fair leadership style on job satisfaction. Finally, the study considered the relationship between personality trait neuroticism and transformational leadership style as well as personality trait 
extraversion and transformational leadership style. The study used Pearson correlation test and verify that nine out of ten hypotheses have been confirmed and the relationship between Laissez - fair leadership style and job satisfaction is not confirmed.

\section{Acknowledgment}

The authors would like to thank the principles of various schools for cordially cooperating in this survey.

\section{References}

Turiano, N.A., Mroczek, D.K., Moynihan, J., Chapman, B.P. (2013). Big 5 personality traits and interleukin-6: Evidence for "healthy Neuroticism" in a US population sample. Brain, Behavior, and Immunity, 28, 83-89

Cronbach, L. J. (1951). Coefficient alpha and the internal structure of tests. Psychometrika, 16(3), 297-334.

Di Fabio, A., \& Busoni, L. (2007). Fluid intelligence, personality traits and scholastic success: Empirical evidence in a sample of Italian high school students. Personality and Individual Differences, 43(8), 2095-2104

Likert, R. (1932). A Technique for the Measurement of Attitudes. Archives of Psychology, 140, 1-55.

Lin, I.Y., \& Worthley, R. (2012). Servicescape moderation on personality traits, emotions, satisfaction, and behaviors. International Journal of Hospitality Management, 31(1), 31-42.

Max Chochinov, H., Kristjanson, L.J., Hack, T.F., Hassard, T., \& McClement, S., \& Harlos, M. (2006). Personality, neuroticism, and coping towards the end of life. Journal of Pain and Symptom Management, 32(4), 332-341

Minoretti, P., Politi, P., Martinelli, V., Emanuele, E., Bertona, M., Falcone, C., \& Geroldi, D. (2006). QT interval duration in apparently healthy men is associated with depression-related personality trait neuroticism. Journal of Psychosomatic Research, 61(1), 19-23.

Takano, A., Arakawa, R., Hayashi, M., Takahashi, H., Ito, H., \& Suhara, T. (2007).Relationship between neuroticism personality trait and serotonin transporter binding. Biological Psychiatry, 62(6), 588-592 